\title{
O TOMBAMENTO DA GRUTA DE ANGICO: disputas da memória do cangaço no sertão nordestino
}

\author{
Vagner Silva Ramos Filho*
}

\begin{abstract}
RESUMO: o trabalho discute a cultura da memória contemporânea do cangaço, fenômeno de banditismo do nordeste brasileiro, atentando-se principalmente às rememorações e comemorações do cangaceiro Lampião, mais conhecido como o "Rei do Cangaço". Busca-se entender, em particular, a historicidade das ações e representações relacionadas à "Gruta de Angico", local onde os principais cangaceiros morreram e que depois transformou-se em local de culto ao cangaço. Para tanto, analisamos os acordos e conflitos em torno do processo de tombamento da Gruta ao longo da década de 1980, observando as variações do lugar da memória do cangaço na temporalidade nordestina, a fim de problematizar ditas identidades regionais.

PALAVRAS-CHAVE: Cangaço; Nordeste; Lampião; Patrimônio.
\end{abstract}

\section{Angico cave as heritage: disputes of the memory of cangaço in the Brazilian northeastern hinterland}

\begin{abstract}
Cangaço, a banditry phenomenon from the Brazilian Northeast region, by focusing on recalling and the subsequent celebrations connected to Lampião as well, best known as "King of Cangaço". It aims at understanding, mainly, the historicity of the actions and representations related to "Gruta de Angico" (Angico Cave), the place where the most important cangaceiros (bandits of Cangaço) died and which was later transformed into a place of cult and worship. Hence, we analyzed the agreements and conflicts around the cave site heritage official preservation process, throughout the 1980's, highlighting the movements of this place of the memory of Cangaço in a northeastern temporality, aiming at debating the so called regional identities.
\end{abstract}

KEYWORDS: Cangaço; Brazilian Northeast; Lampião; Heritage.

\section{Cueva de angico como patrimonio cultural: disputas de la memoria del cangaço en el sertón nordestino}

RESUMEN: El trabajo debate la cultura contemporánea del Cangaço, fenómeno de la bandidaje del nordeste brasileño, enfatizando principalmente los recuerdos y conmemoraciones del cangaceiro Lampião, más conocido como el "Rey del Cangaço". Se trata de entender en particular la historia de las acciones y representaciones relacionadas a la "Gruta de Angico", donde los principales cangaceiros murieron transformándose en local de culto al cangaço. Para eso, se analizaron acuerdos y conflictos en torno del proceso de Patrimonio Cultural de la Gruta a lo largo de la década de 1980, observando las variaciones del lugar referente a la menoría del cangaço a lo largo del tiempo nordestino, con la finalidad de problematizar dichas identidades regionales.

PALABRAS CLAVE: Cangaço; Nordeste; Lampião; Patrimonio.

\footnotetext{
*Mestre em História pela Universidade Federal do Ceará (UFC). Pesquisador do Grupo de Estudo e Pesquisa em Patrimônio e Memória (GEPPM-UFC/CNPq) e do Grupo de Pesquisa História Popular do Nordeste (HPOPNET-UFS/CNPq). Atualmente é professor substituto no Departamento de História da Universidade do Estado do Rio Grande do Norte (UERN-Assú). Contato: Rua Sinhazinha Wanderley, 871, Centro, 59650-000, Assú - RN, Brasil. E-mail: vagner_ramosf@hotmail.com. ORCID: https://orcid.org/0000-0002-1268-7079.
} 


\section{A memória do cangaço, a temporalidade nordestina e a Gruta de Angico}

No dia 13 de maio de 1982, um pedido de preservação inusitado, cujo enfoque era o cangaço, chega à mesa do Conselho Estadual de Cultura de Sergipe. A inóspita Gruta de Angico, local onde o cangaceiro Lampião morreu, está no centro do debate. Depois da exibição nacional de uma minissérie sobre esse cangaceiro, a Gruta recebe atenção diferenciada, ganha status de cultura e vira objeto de muitos interesses. Sob justificativa de que o dono da fazenda onde fica o local teria dito que poderia destruí-la, o pedido feito por um representante do próprio Conselho, o economista Luiz Fernando Ribeiro Soutelo, encerra sua retórica afirmando que tombar a Gruta era uma forma de "preservar uma fase que não pode ser julgada pelo gosto e não gosto das pessoas".

O processo de tombamento da Gruta, uma das primeiras ações de preservação oficial acerca do cangaço na contemporaneidade, é um marco memorial significativo. Para entender o processo no qual esse imbróglio está inserido, algumas indagações são centrais: como a análise das variações da memória cangaceira enquanto elemento de estruturação da temporalidade nordestina ajuda a problematizar identidades regionais? Como essa discussão pode ser elucidada pelo tombamento de Angico? Como entender os dilemas em torno dessa memória tomada como patrimônio cultural?

O propósito deste texto é refletir sobre as marcas da cultura da memória no tempo presente, visando compreender ressignificações da memória cangaceira no período, percebendo seu fortalecimento na cena pública e problematizando-a como fruto de um "passado que não passa"; investigar o tombamento de Angico, notando a atuação de determinados grupos sociais em momentos centrais do processo e as justificativas usadas para valorar o local; problematizar as várias disputas de ações e representações em cena, vislumbrando formas de entendê-las sob a luz do campo do patrimônio.

$* * *$

Que existe uma extensa bibliografia acerca do cangaço não restam dúvidas $(C f$. WIESEBRON, 1997). Sua historiografia pouco tem oxigenado, entretanto, o debate efetivo em torno de certas facetas que subsistem sufocadas, porque geralmente se vem deixando de lado o estudo da "dimensão de sua repercussão na cultura brasileira contemporânea" (ARAÚJO SÁ, 2011, p. 133). A temática da memória é uma constante nessa lista, mas a grande maioria dos trabalhos parece abordá-la mais como fonte do que enquanto objeto de investigação, o que não significa dizer que importantes obras não tenham lançado bases expressivas para o entendimento de como os cangaceiros são vistos pela sociedade $(C f$. 
HOBSBAWM, 1969; QUEIROZ, 1977; GRUSPAN, 2006). Nos últimos anos houve relativo aumento de pesquisas que têm se dedicado diretamente à memória no tempo presente $(C f$. CLEMENTE, 2009; ARAÚJO SÁ, 2011; FALCÃO, 2013; FERREIRA Jr, 2014). Ao buscarem interpelar as construções mnemônicas entre jogos de lembranças, silêncios e esquecimentos, elas têm sido pertinentes para a elucidação de determinados problemas em torno do assunto.

O cangaço foi um fenômeno de banditismo vivenciado no sertão do Nordeste brasileiro entre a segunda metade do século XIX e a primeira metade do século XX. Entendese banditismo como prática reconhecida oficialmente como um tipo de criminalidade. Mesmo que o cangaço não se reduza a simples manifestação marginal, pois imbuiu-se de diversidade de elementos que forneceram-lhe construção sociocultural bastante singular, a amplitude das discussões sobre suas peculiaridades evidencia a fertilidade do debate ( $C f$. MELLO, 1985; BARROS, 2007; PERICÁS, 2010). Virgulino Ferreira da Silva, mais conhecido como o cangaceiro Lampião, é considerado o "Rei do Cangaço". Lampião nasceu no sítio de Passagem das Pedras, atual município de Serra Talhada, estado de Pernambuco, em 1897, e morreu na Gruta de Angico, município de Poço Redondo, estado de Sergipe, em 1938. Nessa mesma ocasião, outros dez cangaceiros também morreram.

Foi nessa conjuntura, em específico nas primeiras décadas do século $\mathrm{XX}$, que foi construída a "comunidade imaginada" (ANDERSON, 2008) que é a região nordestina. Apesar da região concentrar uma realidade múltipla de vidas, sua imagem no senso comum está relacionada a determinados estereótipos: sociedade rural, agrária e artesanal, popular, violenta, religiosa e mística (ALBUQUERQUE Jr, 2013). Em meio a criação desse imaginário, houve corrente associação entre cangaço e Nordeste, porque os cangaceiros transitavam pelos territórios que viriam posteriormente integrar a região. Com o passar do tempo, todavia, o que outrora foi uma associação conjuntural virou uma associação modular, por isso as forjadas ligações são apresentadas como se fossem essenciais. Um típico caso de mito nordestino.

O fim da vivência cangaceira há muitas décadas não impossibilitou que sua memória sobrevivesse em diferentes meios culturais, tais como objetos, oralidades, locais, folhetos de cordel, artesanato, periódicos, fotografias, livros, filmes, músicas etc. que, por sua vez, geraram demais tipos de conservação, transmissão e ressignificação. No terreno das identidades regionais, a memória do cangaço tomada enquanto elemento que confere sentido à temporalidade nordestina é o que entendemos por mito nordestino. A associação entre memória e temporalidade adquire nitidez quando se percebe que "devido à rememoração 
trazer uma marca de anterioridade, ela dá sentido ao tempo, pois instaura uma duração - um antes, um durante e um depois" (RICOEUR, 2007, p. 35). A interpelação dessa paisagem imaginária, que funda visões de identidade, é fundamental porque fornece condições de percebermos seus muitos "estratos de tempo", isto é, suas diferentes durações - ritmos, sensações e variações -, que podem ser tanto de ruptura quanto de continuidade em relação à uma "medida de tempo" referencial (KOSELLECK, 2014, p. 9, 15 e 16) geralmente marcada por estereótipos. A proposta basilar aqui é perceber, então, distintos estratos temporais, relacionados às disputas identitárias, por meio de análise do tombamento da Gruta de Angico.

Nesse itinerário, o campo do patrimônio é ambiente instigante para pensar os modos como uma sociedade trata seu passado através da atribuição de valores aos lugares, às práticas e aos objetos que são tomados como significativos para determinada coletividade, comunidade e grupo. Seguindo a sugestão de Dominque Poulot (2009, p. 12 e 40) de que a "história do patrimônio é amplamente a história da maneira como uma sociedade constrói seu patrimônio", buscamos notar como o patrimônio se mantém "vivo devido às profissões de fé e aos usos comemorativos que o acompanham", bem como os investimentos políticos, éticos e financeiros que o conformam. Eis um caminho crucial para problematizar sua "vocação em encarnar uma identidade".

As memórias do cangaço, no tempo presente, foram amplamente ressignificadas. Com intuito de entender os valores que passaram a contorná-la, precisamos nos situar diante de discussão mais ampla. Afinal, trata-se de tarefa complexa a busca da elucidação de como um passado tão controverso quanto o do cangaço, passível de ser visto como uma derrota histórica, vai sendo transformado até em conquista cultural marcada por dever de transmissão, praticamente uma vitória, no sentido de que a "história de um fracasso coletivo se torna o sucesso de uma empresa de rememoração" (ALBUQUERQUE Jr, 2013, p. 69). Destarte, a explicitação dos debates instrumentalizados para analisar o tema sob essa ótica é essencial para observar como esse cenário vai se formando em diferentes escalas de observação.

No terço final do século XX, conjuntura de redemocratização no mundo ocidental, há um fortalecimento da cultura da memória em nome da tríade - memória, identidade e patrimônio. Segundo Andreas Huyssen, essas décadas foram marcadas por transformações de experiências de espaço e tempo que teriam sido responsáveis pela paulatina substituição de um "futuro presente" por um "passado presente", isto é, o retorno ao passado difere das primeiras décadas da modernidade do século $\mathrm{XX}$ nas quais o futuro foi mais privilegiado. A intensificação da globalização na pós-modernidade possibilitou tal transformação à medida que maiores interações em nível mundial resultaram no "encurtamento das distâncias entre 
diversas localidades e na sensação de se viver exclusivamente no presente devido à aceleração das informações" (HARVEY, 1992, p. 185). Com efeito, umas das implicações transnacionais desse presentismo foi a de que "se o início do século procurou garantir futuros utópicos, o seu fim foi envolvido pela tarefa não menos complicada de assumir a responsabilidade pelo passado" (HUYSSEN, 2014, p. 195).

Alguns vetores desse "boom da memória" (WINTER, 2006) são os seguintes: descentralização de ações e representações mnemônicas que não estão mais restritas a poucas instituições, como o Estado, a Igreja e a Escola (NORA, 1993); o direito à memória mobilizado sobretudo por grupos marginalizados que, ao terem tido suas memórias relegados de marcos oficiais, ressaltam um desejo de tradição que também está ligado à luta por poder (HEYMANN, ARRUTI, 2012); expansão dos suportes da memória com o desenvolvimento da tecnologia da informação que viabilizou maior registro, produção e difusão (SARLO, 2005); interesse do público, demanda por bens culturais e tipos de consumo cultural que acabam fomentando a espetacularização (HARVEY, 1992); ruminação de eventos traumáticos, responsáveis por incitar o dever de memória - compromisso em não esquecer tais passados - a fim de que se consiga extrair alguma lição da dor (HARTOG, 2013).

Todos esses sintomas são indícios para compreender o que David Harvey (1992, p. 289) chama de "condição pós-moderna" da sociedade, a qual é marcada pela "intensificação da globalização, incerteza, fragmentação, efemeridade e descontinuidade". Nessa circunstância, em que o regime de historicidade presentista é mais vivenciado, François Hartog também sugere com sua hipótese que as relações subjetivas com o tempo se alteraram. Daí dizer que o "futuro não é mais um horizonte luminoso rumo ao qual caminhamos, mas uma linha de sombra que colocamos em movimento em nossa direção, enquanto parecemos patinar no campo do presente e ruminar um passado que não passa" (HARTOG, 2013, p. 245).

A preocupação global com os traumas do passado, somados aos receios de futuro, foram decisivos para que a temporalidade contemporânea fosse dominada pelo presente. Por sua vez, esse presente não deixa de viver desorientado entre o que não pode ser esquecido e a incapacidade de imaginar o porvir (REIS, 2012). Nessa propriedade, os tais "passados que não passam" são tipos de passados que as pessoas não querem ou não conseguem se desvencilhar facilmente, o que geralmente está relacionado às memórias dolorosas, por isso que o dilema - lembrar ou esquecer - ecoa tão forte quando são colocados em pauta. Cunhada na segunda metade da década 1980, em meio aos acalorados debates sobre "negacionismo", "revisionismo" e "relativismo", a expressão foi usada para referir-se às memórias dolorosas 
da Segunda Guerra Mundial na Alemanha e França, mas passou a ser aplicada a outras memórias, como a da União Soviética, na Rússia; do Apartheid, na África do Sul; e das Ditaduras Militares, na América Latina (VARELLA, 2012). A característica do dilema fez com que outras memórias, não situados necessariamente nesse panorama, também ganhassem essa conotação.

Com o incentivo ao direito à memória, dimensão básica da cidadania que se aspirava construir em novo contexto, uma profusão de "memórias subterrâneas" (POLLAK, 1989), questionadoras em potencial de marcos memoriais oficiais, conquistaram força no cenário público, operando simultaneamente uma "fragmentação de identidades homogêneas" (HALL, 2011) que, em outros termos, pode significar redefinição de temporalidades nacionais, regionais e locais, e reivindicação de "novos patrimônios" (POULOT, 2009) por grupos sociais que não se reconheciam nas heranças antes instituídas.

Nesse período, as valorações que demarcam o patrimônio suscitaram várias discussões públicas. Para Dominique Poulot (2009, p. 199 e 228), o fim do século XX assistiu ao "reconhecimento de novos patrimônios que resultam de uma profusão de esforços públicos e privados em favor de múltiplas comunidades e estão longe da definição canônica de herança cultural", sendo que muitos dos seus "usos são instrumentalizados na via do desenvolvimento econômico em função do turismo". Para Gilberto Nogueira (2014, p. 52), os debates sobre patrimônio foram acompanhados de mudanças conceituais elaboradas em "perspectiva com os anseios de novos sujeitos históricos que entraram em cena e forjaram a necessidade de se repensar os silêncios e os ocultamentos, assim como o que deve ser protegido, valorizado e repertoriado".

Em consonância, ressalta-se a importância das ideias de John Tunbridge e Gregory Ashworth (2007, p. 36) sobre o chamado patrimônio dissonante para notar a "contestação inevitável do patrimônio em função das discordâncias quanto ao seu valor". Cristina Meneguello, de maneira semelhante, reflete acerca das memórias difíceis - desprovidas de glamour histórico ou dolorosas - que conformam os "patrimônio sombrios", cujas dissonâncias trazem a constante indagação: "o que ocorre quando não se quer ou não se pode preservar o passado?" Partindo disso, a autora discute memórias de regimes totalitários e ditatoriais. Por um lado, Meneguello (2014, p. 54 e 60) ressalta como o "patrimônio não é apenas um relicário de testemunhos estéticos da atividade humana, visto que ele fala do dever de rememoração e de dívida para com as vítimas de crimes de Estado"; por outro, atenta para certas valorações que podem desembocar na transformação do 'lugar de barbárie' em 'lugar de cultura' e torná-lo repositório de souvenir. A atenção advém de sua observação à prática do 
chamado Dark Tourism que "ao invés de ter um olhar crítico ao ocorrido em lugares traumáticos se prende mais a excitação do risco".

Em relação ao contexto brasileiro, com a redemocratização política pós-1985, cujo marco na luta pela ampliação cidadã foi a promulgação da Constituição de 1988, houve um alargamento do significado de cidadania. Resultante da concepção do "direito a ter direitos", a dilatação facultou a criação de legislação baseada na premissa de que o que "está em jogo é o direito de participar da própria definição do sistema que tem de incorporar tanto a noção de igualdade quanto a de diferença" (PEREIRA, 2011). Nesse conjunto figurou o exercício do "direito à memória" que amparava legalmente a reorganização de referenciais da temporalidade nacional. Por muito tempo, as memórias de grupos ditos elitistas, hegemônicos e dominantes foram constituídas como marcos emblemáticos para a sociedade. Em função da contraposição aos marcos instituídos na temporalidade oficial, da busca de redefinição identitária capaz de contemplar a multiplicidade cultural, da recorrência à auto-historicização e/ou demais motivos, emergiram memórias de grupos ditos populares, subalternos e revoltosos.

A forjada relação entre memória do cangaço e temporalidade nordestina precede o tempo presente, assim como sua valoração não é nenhuma novidade presentista. $O$ diferencial, para além do recorte temporal, apresenta-se na participação diversificada de instituições, grupos e indivíduos em tais iniciativas, o que, por sua vez, desdobra-se na maior presença dessa memória no cenário público, visível através da criação de museus, entidades comprometidas com seu dito resgate, comemorações e demais ações que se multiplicaram nesse momento da redemocratização.

A partir desse panorama, pode-se sinalizar que foi no terço final do século XX, sobretudo no período de redemocratização brasileira que assistiu à emergência de memórias marginalizadas da cena oficial - indígena, negra e sertaneja -, que a memória do cangaço entrou mais em pauta. Parece ser válido afirmar que existe um movimento nordestino de ressignificação da memória do cangaço que, ao ser incentivado por interesses que circulam entre desejo de tradição, dever de memória e consumo cultural, revisita essa memória questionando estigmas, descasos, censuras, exclusões e silêncios que consideram ter sido historicamente impostos, o que redefine seu lugar na temporalidade nacional, nordestina e local. Alguns marcos dessa ressignificação podem ser vislumbrados: a exibição televisiva nacional do seriado "Lampião e Maria Bonita", na década de 1980, a criação da Sociedade Brasileira de Estudos do Cangaço (SBEC), na década de 1990, e a consolidação da "Missa do Cangaço" na Gruta de Angico, na década de 2000. Contudo, não se pode perder de vista as 
contendas em torno dessa memória conflituosa, cercada de feridas abertas em seus mais variados corpus. As insatisfações são reveladas, principalmente, pelas vítimas do cangaço, por seus descendentes e por demais grupos que, além de não se identificarem com essas proposições, incomodam-se com o que acreditam ser a "glorificação", o "endeusamento" e a "apologia" do cangaço.

As ressignificações, valorações e negociações dos conflitos da memória cangaceira são fortemente manifestadas por uma premissa do início dos anos 1990 que vem se tornando cada vez mais ordinária, categórica e até estratégica: a ideia de que "Lampião não é nem bandido, nem herói, ele é história!" 1. Na região nordestina, existem numerosas variações mnemômicas. Obviamente, o curto mapeamento não contempla todas as possíveis interfaces aí envolvidas. Entretanto, parece-nos que tal busca memorial constitui singular amostra de como o fenômeno situa-se no tempo presente, provavelmente inserido no corolário do aforismo "um passado que não quer passar", máxima bastante utilizada em alusão às experiências presentistas de tempo por indicarem responsabilidade com o passado e por carregarem em seu bojo dilema recorrente para os nordestinos: lembrar ou esquecer?

\section{O tombamento da Gruta em três tempos}

O processo de tombamento da Gruta de Angico, aberto no início da década de 1980, através do Conselho Estadual de Cultura de Sergipe (CEC-SE), trata-se de um marco dos acordos e das disputas do tema, logo, figura como expressão sintomática da sua patrimonialização. ${ }^{2}$ A documentação compilada no processo inclui ofícios, cartas, relatórios técnicos, notícias, fotografias, panfletos, cartazes de comemorações etc. A forma como esses documentos foram organizados no arquivo sugere apreciação que parece caminhar inevitavelmente ao tombamento. Para perceber suas nuances dissonantes, estivessem elas abertas ou veladas, foi preciso fazer leitura a contrapelo atenta ao modo como muitos grupos, com diferentes sensibilidades patrimoniais que incidiam em posicionamentos favoráveis ou contrários, envolveram-se no processo ao longo dos anos. ${ }^{3}$

Constatam-se, por um lado, envolvimentos individuais do proprietário do local; de familiares de ex-cangaceiros, de volantes e de vítimas do cangaço; de jornalistas; de memorialistas; de artistas; de intelectuais; de professores; de políticos; de empreendedores culturais; de militantes sociais e; por outro, participações coletivizadas através de instituições como o Conselho Estadual de Cultura (CEC-SE); a Universidade Federal do Sergipe (UFS); o Departamento de Preservação Histórica (DPHA); a Fundação Estadual de Cultura 
(FUNDESC); a Empresa Sergipana de Turismo (EMSETUR); o Instituto do Patrimônio Histórico e Artístico Nacional (IPHAN); e o Centro de Cultura Popular Zé Julião.

Quando se trata de abordar um lugar como Angico, o interessante é investigar, em geral, que, como sugere Aleida Assman (2011, p. 317), “o lugar pode reativar a recordação das pessoas, assim como as rememorações das pessoas podem reativar a recordação do lugar”. Diante disso, buscamos atentar para variações mnemônicos em torno das justificativas que tentavam tornar a Gruta um local de valor representativo para a temporalidade nordestina. Após historicizá-la, abordamos o processo em três momentos, percebendo a atuação de grupos sociais que surgem com frequência na documentação: a abertura do pedido do tombamento (1982) com a atuação dos intelectuais do CEC-SE; a comemoração ao cinquentenário de morte de Lampião (1988) com os empreendedores da memória de Poço Redondo; a luta pela preservação que resultou no tombamento estadual com os membros da Rede Globo de televisão e de funcionários da Secult-SE (1989).

$* * *$

A Gruta de Angico, situada no município de Poço Redondo-SE, foi palco de derradeiro confronto do cangaço. Em 1938, os cangaceiros Lampião, Maria Bonita e mais nove cangaceiros do seu bando foram mortos em combate contra a volante do tenente João Bezerra. A memória da morte logo se incrustou no local. Nas décadas posteriores ao combate, as atenções ao local foram particulares e esporádicas. Atraiam alguns poucos familiares dos cangaceiros mortos, antigos conhecedores das redondezas, pesquisadores do cangaço e curiosos. As práticas de colocação de cruzes em ato de condolência aos mortos de Angico, realizadas nos anos 1950 por João Ferreira, único irmão de Lampião que não entrou para o cangaço, e no começo dos anos 1960 pelo mesmo tenente João Bezerra, que liderou a investida que resultou na morte do cangaceiro, foram responsáveis por reativar mais ainda a memória fúnebre lá incrustada.

A atenção pública de Angico veio depois. Resulta de algumas produções midiáticas, como as feitas pela Rede Globo, emissora aberta de maior audiência no país, que exibiu o documentário $O$ último dia de Lampião, em 1975, e a minissérie histórica Lampião e Maria Bonita, em 1982. ${ }^{4}$ Embora os produtores não tenham visitado a Gruta, eles dirigiram encenações dos combates travados no local para serem exibidos nas obras, pois tratavam dos momentos finais da vida do cangaceiro. O alcance das produções, sobretudo da minissérie, foi consideravelmente alto, uma vez que mais da metade da população brasileira possuía aparelho televisor em seus domicílios no período. 
A memória do cangaço podia ser bem conhecida, mas apenas nesse momento sua projeção estava literalmente em tela para o grande público através da mídia nacional. Assim, o crescente entusiasmo pela Gruta, por muito tempo tomada como um local inóspito, desagradável e esquecido, não chega a surpreender tanto se atentamos para sua centralidade no tema que vinha fazendo sucesso com a minissérie Lampião... exibida em oito episódios entre 26 de abril e 05 de maio de 1982. Por conseguinte, a reativação da memória que a exibição gerou atraiu interesses diversos, criou demanda de debate sobre o assunto e suscitou várias tensões na cena pública.

Figura 1 - Seriado "Lampião e Maria Bonita"

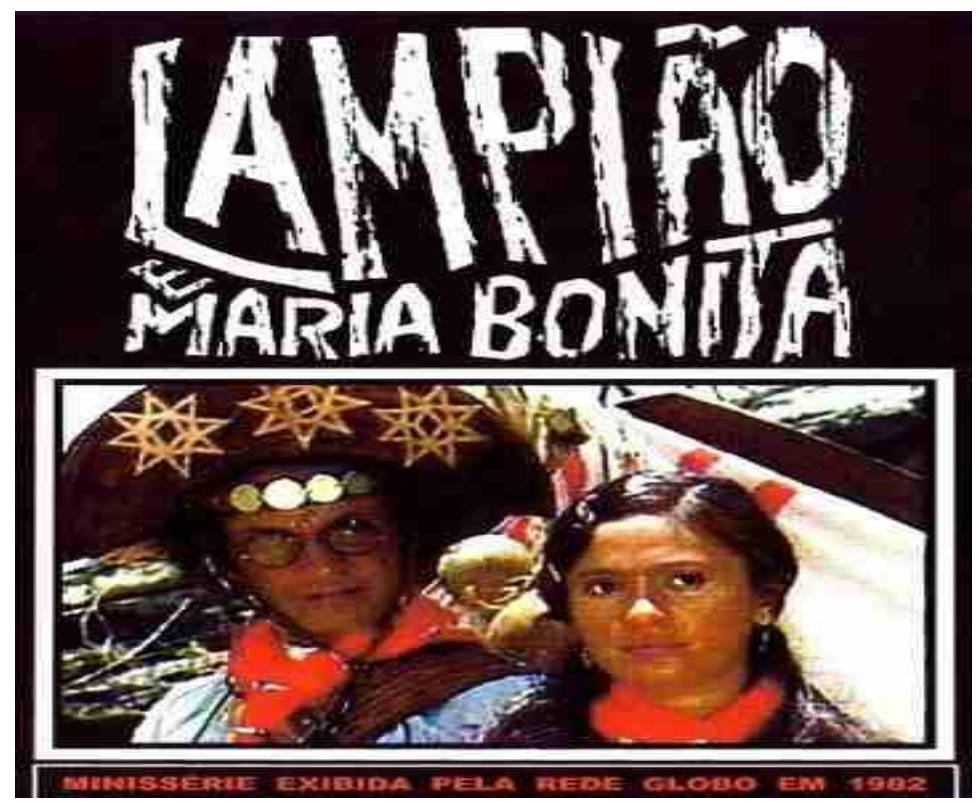

Fonte: Rede Globo de Televisão

No dia 12 de maio de 1982, informações acerca da Gruta são divulgadas pela Gazeta de Sergipe, periódico de circulação diária no estado que, por considerá-las extremamente graves, concede primeira página no editorial "Incidente em Angico". 5 Basicamente, trata-se de uma denúncia. Semelhante ao letreiro que embala o desfecho da supracitada minissérie "Lampião e Maria Bonita não foram esquecidos e são hoje mitos nacionais" -, o escrito afirma que o "casal famoso é um dos mais ricos e famosos para a história e a cultura da região". Apesar de ressaltar que houve muita ficção, já que não apresentaram "Lampião como alguém perverso, sanguinário e capaz de matar friamente", sinaliza que o importante mesmo foi ver um "trabalho com bom profissionalismo e bom acabamento cênico" motivar o "País inteiro a acompanhar os capítulos da minissérie". Depois de suscitar cautelosamente interesse pela controversa temática, o incidente é finalmente anunciado - querem destruir a Gruta de Angico. 
No editorial, afirma-se enfaticamente que, após o proprietário da fazenda onde fica a Gruta saber das intenções de reportagem e visita ao lugar manifestadas pelos produtores e pela filha de Lampião, ele teria dito em "tom grave e ameaçador que nada tinha a ver com a cultura e que destruiria o antigo pouso do "Rei do Cangaço"”, causando o "espanto dos jornalistas do sul do país". Para contornar a polêmica surgida no local, sinaliza-se que foi necessário solicitar a intervenção do "Juiz da Comarca de Porto da Folha e do Destacamento Policial", responsável oficial pela área, dando a entender que tudo era feito para que todo o "bom trabalho" continuasse e fosse exibido para "dezenas de milhões de brasileiros que apreciam as estórias ainda hoje contadas do mais expressivo dos vultos populares do Nordeste". Em sua parte derradeira, imputa que o "Estado pode e deve zelar pelo passado", advogando que a Gruta deve ser "declarada de interesse cultural para fins de tombamento". Com tom de ironia, encerra logo depois dizendo que "Lampião é, com toda a certeza, um mito nacional que tem despertado o interesse de estudiosos em muitas partes do mundo" e, caso "fosse um mito norte-americano, em cada canto por onde houvesse passado haveria um marco e alguém estudando. Mas é em Sergipe, e aqui, infelizmente, a história é outra”.

O editorial é estruturado de forma que, independente das facetas mais cruéis de Lampião, o público perceba que a dita recusa de acesso à Gruta e ameaça de destruição eram inadmissíveis. A falta de abordagem dos motivos que podem ter gerado a suposta atitude no proprietário do local sugerem implicitamente que tudo não passava de ignorância. Com boa dose de retórica, solicita providências do poder público para resolução do problema propondo um tombamento. Paralelo à intenção de informar o caso, o editorial busca formar certo encargo instigando a mobilização pública em torno de causa que precisava de adesão. Diante das exposições, a necessidade de tombamento do local figura como ordem quase inconteste, um dever de memória urgente. Por conta disso, o escrito não pode ser entendido como queixa dispersa, pois mais parece ser resultado de ações articuladas com interesse de viabilizar a preservação do local.

Nesse primeiro momento, os intelectuais sergipanos do CEC-SE, órgão normativo, deliberativo e consultivo da política cultural sergipana, foram alguns dos que tomaram para si a missão da preservação de Angico. O Conselho foi criado em 16 de agosto de 1967 por meio da Lei Estadual $n^{\circ} 1.478$, no contexto de reconfiguração da gestão pública da cultura em âmbito nacional no início da Ditadura Civil-Militar brasileira, com intenção de manter a “'fruição cultural sob o controle e a intervenção do novo regime', assegurar coordenação de programas nacionais e ser um mediador das demandas regionais e locais”. No período de reabertura política, o Conselho foi reestruturado pela Lei Estadual 2.770 de 22 de dezembro 
de 1989 e teve sua atuação ampliada. É composto de quatorze "personalidades representativas da cultura sergipana", dentre as quais quatro representantes de entidades e/ou instituições culturais privadas, todos escolhidos e nomeados a critério do governador (PASSOS, 2013).

As competências dos intelectuais do CEC-SE passam por "apreciar o Plano Estadual da Cultura", fazer "pronunciamento pelo tombamento de bens culturais a ser realizado pelo poder público" e "difundir e valorizar a cultura nas diversas camadas da população". No campo da preservação, cabe aos seus integrantes solicitar, analisar e emitir parecer sobre processos de tombamento em nível estadual. Com a crescente repercussão da Gruta, alguns intelectuais parecem ter se instigado com os vários ecos surgidos e se viram na competência, por interesse interno e pressão externa, de se envolver, já que ela vinha recebendo status de bem cultural. Para além disso, o certo é que entraram em terreno problemático, pois, por um lado, a maioria dos bens preservados nas políticas culturais sergipanas estavam ligadas às memórias de grupos dominantes e, por outro, o tema era por si só polêmico no estado. Porém, os intelectuais não eram os únicos interessados e relações com outros grupos podem ser percebidas.

O primeiro sinal de articulação entre atuação dos intelectuais, uso da imprensa e tentativa de preservação não custou a aparecer. No dia posterior ao Incidente..., uma indicação oficial de tombamento é enviada ao CEC-SE que, em caso de aprovação, seria direcionada à Secretaria de Cultura do estado para apreciação do governador de Sergipe, o responsável final pela oficialização de preservação. A indicação, amplamente baseada no alarmante editorial, é assinada pelo economista e membro do Conselho Luiz Fernando Ribeiro Soutelo. A abertura de pedidos por integrantes do órgão, conhecedores em potencial dos trâmites burocráticos, é relativamente comum. Contudo, a agilidade com que este foi aberto sugere que o assunto, sensível como era, vinha sendo ruminado pelo conselheiro e que parecia existir uma mínima articulação mobilizada nos bastidores entre demais grupos para se alcançar a finalidade. $\mathrm{Na}$ justificativa, lemos o seguinte:

\footnotetext{
"Senhores Conselheiros,
}

Considerando os fatos evidenciados pelo editorial da GAZETA DE SERGIPE, em sua edição do dia 12 de maio corrente (cópia anexa), segundo o qual o proprietário da fazenda Angico 'não permitiu que a Rede Globo fizesse reportagem' (para uma série recentemente realizada e divulgada a nível nacional), negando ainda à filha de Lampeão a visita ao túmulo do seu pai;

Considerando que, ainda segundo informação do mesmo jornal, afirmara o proprietário da fazenda que 'destruiria o antigo pouso do 'Rei do Cangaço';

Considerando que a 'Gruta de Angico, por tudo o que representa para a história, a sociologia, o conhecimento do cenário onde viveu e morreu Lampeão, merece ser declarada de interesse cultural para fins de tombamento, preservando uma fase que 
não pode ser julgada pelo gosto e não gosto das pessoas, mas sim pela evidente contribuição ao estudo social do meio nordestino, com suas figuras, algumas ásperas e viris como o Virgulino Ferreira da Silva;

Considerando que, por disposição constitucional, cumpre ao Poder Público proteger os monumentos que possuem importância histórica, artística, etnográfica e paisagística, assim como os documentos de interesse cultural;

Considerando ser a Gruta de Angico um dos sinais evidenciais da História Social do Nordeste Brasileiro;

Indico ao Excelentíssimo Senhor Governador do Estado, através do Secretário de Estado da Educação e Cultura, a decretação do tombamento da Gruta de Angico como monumento de interesse histórico e paisagístico e, em caso especial, a declaração de utilidade pública para fins de desapropriação.

Sala das Sessões do Conselho Estadual de Cultura, em Aracaju, 13 de maio de 1982. Luiz Fernando Ribeiro Soutelo - Conselheiro (grifo nosso) ${ }^{6}$

Nessa justificativa, a grande celeuma parecia sustentar raciocínio coerente para se preservar um ambiente marcado pela passagem de figuras que eles próprios consideravam como "ásperas", apesar de serem "viris". Todavia, o argumento do "interesse cultural" do local praticamente não é desenvolvido e aparece em tom de imposição ao se afirmar que o tombamento poderia "preservar uma fase que não pode ser julgada pelo gosto e não gosto das pessoas", auxiliando uma "evidente contribuição ao estudo social do meio nordestino". O mais importante é perceber como a Gruta vai deixando de ser simplesmente lugar de morte de cangaceiros para ser valorada como lugar representativo da "História Social do Nordeste Brasileiro".

No CEC-SE, o pedido de tombamento entra em pauta de análise e passa por algumas alterações no seu argumento. Depois de dois meses da indicação, os integrantes do Conselho "batem o martelo" a favor do pedido. No parecer, escrito pela acadêmica conselheira Maria Thetis Nunes, que apresenta um posicionamento favorável, existem duas modificações significativas. Enquanto a primeira lança considerações sociológicas, a segunda aponta impactos negativos do avanço econômico no lugar:

está o cangaceirismo intrinsecamente ligado a uma fase da evolução do Nordeste brasileiro, devendo ser visto como um fato social, e na definição de Manuel Bomfim, 'como reação mórbida, se quiserem, mas inevitável, numa população forte, e quem a ordem normal nenhuma possibilidade oferece de boa atividade social e política'. (...) que a possibilidade de desenvolvimento econômico que se vem processando no Nordeste brasileiro venha a apagar o cenário onde se desenrolou o cangaceirismo e, assim, dificultando a compreensão desse fenômeno pelos estudiosos. (grifo nosso) ${ }^{7}$

A justificativa indica que os conselheiros buscaram refinar cientificamente os argumentos anteriores, pois pareciam explicar, mas não justificar de forma convincente a 
preservação do polêmico local. Por um lado, a ideia de que Angico representa "fase que não pode ser julgada pelo gosto ou não gosto" é lapidada ao colocar que o "cangaceirismo" deve ser visto como "fato social da evolução do Nordeste brasileiro" e as qualificações "ásperos" e "viris" dadas aos cangaceiros são incrementadas com afirmação de que o cangaço é "reação enferma" e "inevitável de uma população forte" que carece de "boa atividade política e social”. Por outro lado, pontua-se que a "destruição" da Gruta poderia vir de investimento econômico desastroso na área.

Depois dessas modificações, a indicação de tombamento é enviada no dia 16 de julho para Antonio Manoel de Carvalho Dantas, o Secretário do Estado de Educação e Cultura, que, após apreciação, deveria repassá-la ao governador Djenal Tavares Queiroz. A recepção do documento, entretanto, parece não ter encontrado o eco que os conselheiros do CEC-SE almejavam. Pela ausência de resposta oficial no processo, pode-se conjecturar que o pedido encontrou algum tipo de objeção. A constatação relativiza o pedido de tombamento colocado como necessidade de primeira ordem. Mas isso não quer dizer que a atuação dos intelectuais não tenha alcançado repercussão em outros cenários culturais, até porque eles não eram os únicos interessados no assunto.

Defronte às memórias difíceis, surgem muitas indagações e as necessidades de preservação não alcançam facilmente o consenso preciso entre as partes responsáveis. $\mathrm{O}$ debate pode ser alongado por mais tempo do que o vislumbrado. Foi o que aconteceu com o pedido de tombamento da Gruta, que só voltou a ganhar espaço em outra circunstância: nas comemorações do cinquentenário de morte de Lampião, em 1988.

Nesse segundo momento, marcado pela redemocratização do país, houve uma reanimação do debate. Com isso, o cinquentenário da morte do cangaceiro transformou-se em importante espaço de discussão das demandas do tema. No município de Poço Redondo, a gestão do então prefeito Alcino Alves da Costa, descendente de ex-cangaceiro, foi igualmente importante nessa alçada por ter investido na pauta da preservação. ${ }^{8} \mathrm{O}$ fato de Lampião ter sido morto na localidade fez com que os eventos sergipanos tivessem mais intensidade do que em outros estados nordestinos, visto que alguns não chegaram nem a promover evento com caráter oficial.

No evento em Poço Redondo, o programa comemorativo oficial congregou-se em torno do "I Simpósio Regional sobre o Cangaço: 50 anos da chacina de Angico (1938 1988)", realizado nos dias 26, 27 e 28 de julho de 1988, no mercado municipal da cidade. A programação, incentivada pela prefeitura, contou com palestras de professores do departamento de História da Universidade Federal de Sergipe (UFS), exibição de filmes, 
apresentação artística de grupos folclóricos e divulgação de materiais com informações sobre o fenômeno do cangaço que circulam entre sua presença em Sergipe, a trajetória de Lampião do nascimento à morte, os combates entre cangaceiros e volantes, curiosidades e algumas frases de efeito do tipo: "homem nenhum nasceu para ser pisado". 9

Figura 2 - Cartaz de comemoração

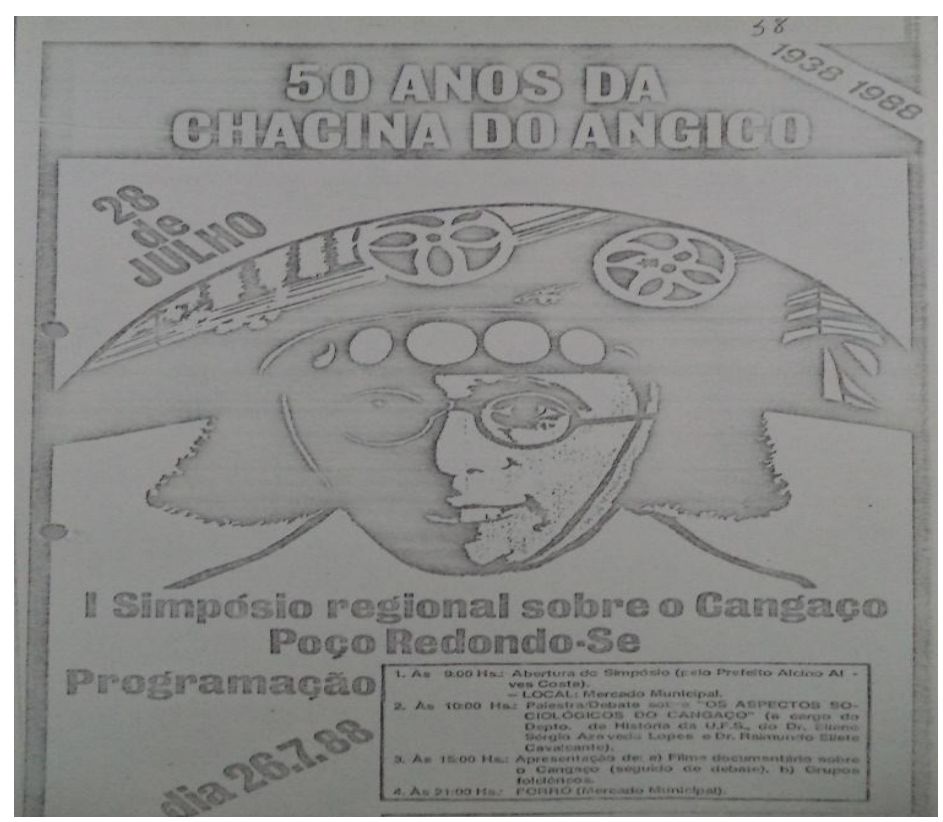

Fonte: Subsecretaria de Estado do Patrimônio Histórico e Cultural de Sergipe (SUBPAC-SE)

A participação social foi ampliada. Os variados grupos envolvidos, que não se restringiam à seara da intelectualidade, manifestaram suas opiniões sobre o tema, tais como alguns empreendedores da memória que colocaram em pauta seus projetos. Por ser um local propenso à altercação, certamente suscitou inúmeras polêmicas. No decorrer do evento, um ato específico, que parecia sintetizar parte dos assuntos que mais tentavam promover, chama atenção. No caso, os organizadores apresentaram, no dia 27 de julho, uma carta pública intitulado Carta do Angico. Vejamos o seu conteúdo:

Por ocasião da visita à GRUTA DE ANGICO, cenário fatídico da tragédia cangaceiresca, nós participantes do $1^{\circ}$ SIMPÓSIO REGIONAL SOBRE O CANGAÇO, evento alusivo às comemorações do CINQUENTENÁRIO DA CHACINA DO ANGICO, vimos a público reivindicar das Autoridades competentes a desapropriação e o tombamento do sítio geográfico da Gruta de Angico pelo inestimável valor histórico que esse pequeno espaço físico (encravado no Município de POÇO REDONDO no Sertão sergipano) representa para toda a coletividade do Nordeste.

Aproveitamos a efeméride do Cinquentenário da Chacina do Angico para proclamar POÇO REDONDO - A CAPITAL NACIONAL DO CANGAÇO!

A justeza deste epíteto para Poço Redondo faz sentido plenamente, pois sabemos 
que além de abrigar em seu território a Gruta de Angico, foi daqui que ingressou o maior número de cangaceiros em todo Nordeste brasileiro, para o bando de Lampião.

Ao assinarmos a CARTA DO ANGICO estamos convencidos que damos uma grande contribuição para o resgate de um movimento social que controverteu a NAÇÃO BRASILEIRA durante 20 anos seguidos. A verdadeira História de nosso Povo está a exigir um tratamento condigno à altura da importância de diversos Heróis nacionais, Zumbi dos Palmares, Antônio Conselheiro de Canudos e Virgulino Ferreira da Silva, o Lampião.

\section{TUDO PELO SOERGUIMENTO DA CULTURA POPULAR!}

Angico (Poço Redondo/SE), 27/07/1988 (grifo sublinhado nosso) ${ }^{10}$

\section{Figura 3 - "Carta do Angico"}

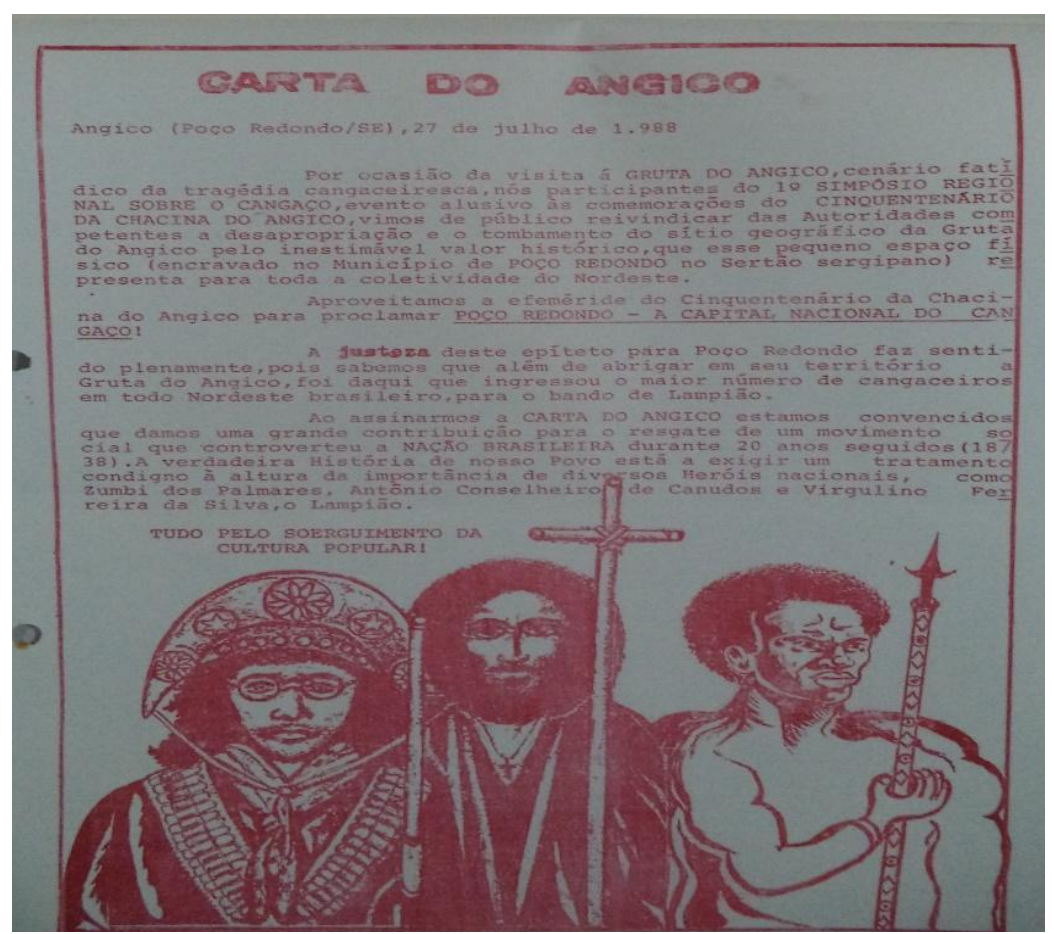

Fonte: Subsecretaria de Estado do Patrimônio Histórico e Cultural de Sergipe (SUBPAC-SE)

A Carta do Angico, em sua intervenção direta nos debates, pontua várias justificativas para o tombamento. Dessa ação, destaca-se a materialização dos discursos com intento de expansão para além do evento e a clareza do escrito para formação de uma mensagem objetiva que pudesse atingir diferentes segmentos, dos eruditos responsáveis pelo tombamento aos populares que poderiam apoiar a iniciativa. $\mathrm{O}$ interessante da carta panfletária é que revela não meramente posições tomadas, mas as razões pelas quais as posições foram tomadas. Que motivava, então, os organizadores do evento?

Nessas comemorações, três aspectos centrais merecem destaque. O primeiro é acerca da valoração de Angico, pois, ao tratá-la como palco de uma "chacina", desvela-se clara 
tentativa de transformar o local de morte em local de memória trágica num esforço de potencialização do dever de memória que parecia ser crucial para a justificativa do tombamento. O segundo é a apropriação da celebração para afirmar orgulhosamente Poço Redondo como "capital nacional do cangaço", não por ter sido o local onde Lampião morreu, mas por ter concedido muitos cangaceiros para o fenômeno, como forma de inserir-se fortemente na disputa com outras cidades nordestinas pelo espólio memorial do tema. $\mathrm{O}$ terceiro é a valorização da cultura popular em face da "nação brasileira" que instiga o enaltecimento de personagens com representações envoltas nos ares de "heróis nacionais", como Zumbi dos Palmares, Antonio Conselheiro e Lampião.

Em conjunto, os três aspectos mostram os motivos da efeméride e o que se procurou demarcar como importante de ser lembrado e esquecido. As comemorações, ao serem vivenciadas enquanto espaços de convergência de interesses, foram igualmente importantes no estabelecimento de contatos que se desdobraram em discussão, proposição e efetivação de iniciativas memoriais. Um indício é que, no ano seguinte, em 1989, parte dos empreendedores que eram os organizadores do evento criaram o "Centro de Cultura Popular Zé Julião" associação cultural cujo objetivo é "estimular o resgate da autêntica cultura popular do Alto Sertão do Sergipe, com destaque ao resgate do Movimento Social do Cangaço”. ${ }^{11}$

$\mathrm{O}$ assunto, todavia, não deixou de ser polêmico. Como sinaliza Antonio Fernando de Araújo Sá, é "interessante observar que esta disputa tem uma evidente vinculação com a política local". Para ilustrar a contenda, pode-se destacar, por um lado, a atuação de Manoel Dionízio da Cruz - militante sindical e ex-presidente da Central Única dos Trabalhadores (CUT) de Sergipe, descendente da Família Félix (Júlio e Manoel Félix da Cruz), coiteiros históricos de Lampião e seu bando - que busca "resgatar essa memória para fortalecer algumas lutas como a da reforma agrária”. Por outro, ressalta-se a liderança política de Ivan Rodrigues Rosa - filho de Durval Rodrigues Rosa, também coiteiro de Lampião, que, sob tortura, junto com seu irmão, Pedro de Cândido, levou a volante do tenente João Bezerra para dar cabo do bando de Lampião, na Gruta de Angico - "que tenta negligenciar a presença dos cangaceiros na região" (ARAÚJO SÁ, 2005, p. 300).

Mas, retornando às comemorações, que reascenderam o debate público da Gruta, o processo de tombamento adquiriu agilidade significativa entre 1988 e 1989. Nesse terceiro momento, os indícios de que dispomos permitem-nos suscitar algumas hipóteses sobre a continuidade. A mais plausível é a de que a campanha pela preservação foi encampada por duas frentes que fizeram oficialmente pedidos de tombamento no segundo semestre de 1988 junto ao Instituto do Patrimônio Histórico Artístico e Nacional (IPHAN). ${ }^{12}$ Por um lado, 
temos o processo $n^{o} 1284-T-88$, articulado por um grupo composto de membros do alto escalão da Rede Globo, que deu início ao projeto provavelmente na matriz do IPHAN no Rio de Janeiro. Por outro, temos o processo $n^{\circ} 650$ de 06/11/1988, feito por membros da SecultSE, que foi iniciado na $5^{\text {a }}$ Diretoria Regional do IPHAN em Sergipe. ${ }^{13}$ A desarticulação entre os projetos sugere certas tensões, mas vejamos apenas as justificativas que usam para o tombamento.

O processo $n^{o}$ 1284-T-88, que teve envolvimento direto do jornalista baiano Edwaldo Pacote, assessor de direção da Rede Globo, foi aberto no máximo em setembro. De concreto, sabe-se que, em 27 de outubro, foi lançado um manifesto artístico ao Ministério da Cultura - assinado por cerca de 80 funcionários da Rede Globo, incluindo atores, jornalistas, publicitários, figurinistas e o então diretor da emissora José Bonifácio de Oliveira Sobrinho, o Boni, vice-presidente da emissora, que demonstrava apoio às famílias dos cangaceiros que vinham lutando pela preservação e pedia celeridade na concretização do tombamento. Dentre outros motivos, fica visível que o interesse da emissora parecia residir nas repercussões da produção da sua minissérie Lampião e Maria Bonita. Reivindicar a preservação da Gruta era uma forma de valorizar sua primeira minissérie histórica e celebrar seu poder de intervenção cultural, já que o pedido de tombamento adveio pouco depois da sua exibição nacional. ${ }^{14}$

Já o processo $n^{o} 650$ de 06/11/1988, de novembro, decorre de articulação da professora Aglaê Fontes de Alencar, então secretária da Secult-SE, órgão que era o competente por levar à frente o processo após os trabalhos do CEC-SE. Destaca-se que, antes disso, em 13 de outubro de 1988, a professora havia enviado ofício solicitando a concretização do tombamento ao doutor Antonio Carlos Valadares, o Governador do Estado no período. O documento era assinado por cerca de 40 funcionários de diversos setores da Secult-SE, pelo presidente da Empresa Sergipana de Turismo (EMSETUR) e por Vera Ferreira, neta de Lampião e Maria Bonita. O diferencial dos demais documentos é que a desapropriação também passa a ser vista como um elemento que permitiria um "fluxo turístico ao local" e que passaria a afirmar não apenas um valor histórico do local, mas um potencial ecológico da área para preservação. A articulação com o governador talvez tenha agilizado a abertura do referido processo em novembro. ${ }^{15}$

Há um elemento no processo que sustenta a afirmação da dupla movimentação direcionada à preservação. Trata-se de correspondência entre o governador de Sergipe e o ministro da cultura brasileira. No começo de fevereiro de 1989, o governador Valadares envia ofício ao ministro José Aparecido de Oliveira sinalizando seu apoio integral ao tombamento do que chama de "quartel general" do cangaço, pois era uma forma de dinamizar a própria 
política cultural do estado. A resposta veio no final do mês. Em tom cordial, o ministro aponta que considerava o processo sobre o "último reduto do cangaço" importante e que estava sob a devida análise. O governador possivelmente fazia referência ao pedido aberto pela Secult-SE, mas o ministro responde mencionando a iniciativa dos funcionários da Globo. A propósito, ressalta-se que, após tomar conhecimento do contato entre os políticos, Edwaldo Pacote envia fax para a professora Aglaê Fontes queixando-se dessa desarticulação que talvez tivesse retardado o processo. ${ }^{16}$

Desse embate, interessa observar que as ações paralelas fortaleceram a reivindicação. Mas, apesar das mobilizações para preservação em nível federal, o tombamento da Gruta em tal esfera não foi concretizado. $O$ desfecho não parece ter sido, todavia, efeito de desarticulação entre os grupos envolvidos. Parece decorrer da falta de concordância mínima acerca da representatividade do local para a esfera federal. Na esfera estadual a ressonância foi diferente. A Secult-SE, que vinha passando por redemocratização em suas políticas culturais e reconhecendo memórias antes relegadas ${ }^{17}$, decide por tombar a Gruta em nível estadual como patrimônio histórico-cultural, pela então recém Constituição Estadual de Sergipe, de 5 de outubro de 1989. A ação envolveu igualmente a preservação de outros bens relativos ao cangaço. No seu artigo 229, consta que "ficam tombados todos os documentos referentes ao cangaço e o sítio histórico da Gruta de Angico, localizada no município de Poço Redondo". 18

Foi apenas em 1996, contudo, que apresentou-se formalmente um documento ao dono da fazenda onde a Gruta se localiza sinalizando que qualquer intervenção na área só poderia ser feita após a prévia autorização oficial. ${ }^{19}$ Depois de muita controvérsia entre o poder público, o proprietário e parte da sociedade sergipana, o local estava oficialmente protegido. Essa situação abriu possibilidade para uso público e contribuiu para que, em 1998, ano de centenário de nascimento e sexagenário de morte de Lampião, lá fosse criada a Missa do Cangaço, um dos principais eventos do calendário festivo do tema. A prática fúnebre de tomar a figura do cangaceiro como injustiçado por ter sido alvo de dito massacre ajuda essa representação a ser uma das mais estáveis no circuito. Frequentar a Missa, entretanto, não quer dizer que se concorde totalmente com tais ideias.

A título de complemento, convém destacar que o processo de tombamento da Gruta em nível federal pelo IPHAN, datado de 1988, foi reaberto em 2007, um ano antes do septuagenário de morte do Lampião, mas ainda não teve desfecho, possivelmente em virtude da controvérsia do seu valor enquanto bem histórico. ${ }^{20}$ Parece que esse foi um dos fatores que fizeram os esforços terem sido direcionados para a preservação ambiental da área. Neste 
referido ano, o governo de Sergipe transformou o local em unidade de conservação da natureza atribuindo-lhe o qualificativo de Monumento Natural de Angico. ${ }^{21}$ Algumas linhas do IPHAN têm atuado em perspectiva parecida.

\section{Um patrimônio cultural nordestino reivindicado, dissonante e contestado}

As valorações em torno da Gruta de Angico indicam diversas contendas. Perscrutar a historicidade da preservação do local é uma maneira de entender, portanto, muitos dos dilemas que envolvem processos de patrimonialização dessa memória difícil do cangaço. Por essa via, é preciso salientar considerações que parecem fazer todo sentido quando pensamos nas especificidades que cercam Angico. Paul Ricoeur, ao tratar da mobilização mnemônica a serviço da reivindicação identitária pontua que ela surge de algumas fragilidades, como a "herança da violência fundadora", pois "aquilo que celebramos como atos fundadores são essencialmente atos violentos legitimados posteriormente por um estado de direito precário", e que a "glória de uns foi humilhação para outros". Ernest Renan, anteriormente, também havia sinalizado acertadamente que o "sofrimento em comum une mais do que a alegria" 22 , enquanto que Aleida Asmann (2011, p. 348) sugeriu a posteriori que os locais marcados por perseguição, humilhação, derrota e morte têm forte valor na memória mítica, nacional e histórica". Vejamos isso por demais ângulos para vislumbrar algumas formas de compreender o tema no campo de estudos do patrimônio.

Em nível de síntese, percebemos como o tombamento da Gruta teve três momentos fundamentais. No primeiro momento, começo da década de 1980, após a repercussão do seriado Lampião e Maria Bonita, os intelectuais do CEC-SE tentam legitimar a demanda de preservação do local defronte às várias polêmicas que a circundam, através de discurso científico, ao postularem importância sociológica para se entender uma fase controversa da história nordestina. No segundo momento, final da década de 1980, com as comemorações ao cinquentenário de morte de Lampião, os empreendedores da memória de Poço Redondo trazem à superfície justificativa mais pragmática que visava extrair lição desse passado que forjam como traumático, logo, com maior capacidade de negociar os conflitos para viabilizar um tombamento. No terceiro momento, em específico no ano de 1989, logo após o referido cinquentenário, os funcionários da Rede Globo e os membros da Secult-SE têm papel destacado na contenda jurídica pela preservação e, apesar de não terem alcançado proteção federal, corroboraram para o tombamento estadual que veio posteriormente.

$\mathrm{O}$ interesse variado pelo tema foi estimulado à medida que se reivindicava o 
tombamento do local pelo seu dito valor nordestino e se tentava minar as objeções à ação preservacionista. Enquanto instrumento revestido de poder sacralizador, o tombamento costuma envolver os bens que protege em áurea mítica. A maioria dos envolvidos considera que a memória cangaceira é significativa na temporalidade nordestina, mas os conflitos em torno do pretenso valor são extensos. Por ser configurado como um "aparelho ideológico da memória”, o patrimônio tem a capacidade de produzir o que Krzysztof Pomian denominou intrigantemente de "semióforos - por indicarem diferentes ordens do tempo". ${ }^{23}$ Uma maneira de vislumbrá-los é notar as representações que se sobressaem em cada iniciativa. Essa “observação das pretensões em torno da memória cangaceira é crucial para perceber o quê do culto pelo patrimônio fica por ele oculto na tensão que se faz constante" em tais jogos mnemônicos. (RAMOS FILHO, 2018, p. 203).

Para alguns que reivindicavam a preservação, o proprietário da fazenda onde fica Angico dizia que ela "nada tinha de cultural", talvez para evitar qualquer alvoroço em sua propriedade, sugerindo que os cangaceiros não mereciam atenção dessa qualidade. Em contrapartida, esses mesmos sujeitos, que lançavam mão de retórica da destruição com frequência por dizerem que o proprietário iria implodir a Gruta a qualquer momento, afirmavam seu valor aproveitando para pontuar que se tratava de um "antigo pouso do rei do cangaço", provavelmente para driblar contendas da trajetória bandoleira que vinham à pauta nos debates, dando a entender que os cangaceiros usavam-na para descanso.

Os intelectuais ligados à Secult-SE, que foram instigados a responder as demandas da preservação, passaram a usar justificativa científica do "valor histórico nordestino da Gruta" destacando que era fundamental para o estudo da região e apontando que os cangaceiros eram uma "reação enferma, porém necessária a uma população forte, desprovida de boa política social". Os empreendedores da memória de Poço Redondo, que traziam justificativas com natureza dita popular e com maior capacidade de negociar conflitos por buscarem extrair lição de um passado que forjavam como traumático, afirmavam que o local teria sido "palco de uma verdadeira chacina", sugerindo que os cangaceiros foram injustiçados e, não obstante, tinham propensão a justiceiros, já que teriam lutado contra desmandos. Os funcionários da Globo, que se envolveram, sobretudo, por conta da valorização que era dada às produções culturais em torno do fenômeno, diziam que a Gruta teria sido "cenário de uma violenta epopeia" protagonizada pelos cangaceiros, o que não poderia deixar de ser destacado publicamente.

Para o citado governador de Sergipe, que se comprometeu com o assunto e viu nele uma forma de qualificar a política cultural sergipana, a Gruta teria sido o "quartel general" do 
cangaço, associando de certa maneira os cangaceiros àqueles soldados que, pela labuta empregada em suas atividades profissionais, merecem reconhecimento. Em resposta à sua manifestação de apoio ao tombamento, o ministro da cultura brasileira, que sinaliza entender a demanda tentando se manter o mais imparcial possível, mostra que a Gruta foi o "último reduto do cangaço", retirando implicitamente o revestimento oficialesco que essas outras valorações traziam aos cangaceiros.

$$
* * *
$$

O movimento de ressignificação da memória do cangaço decorre de fatores que circulam entre desejo de tradição, dever de memória e consumo cultural. O fortalecimento da cultura mnemônica na cena pública da região nordestina acontece principalmente no período do cinquentenário de morte do cangaceiro Lampião. A análise dos acordos e conflitos da memória no período evidenciam que elas parecem ser fruto de um passado que não quer passar nordestino por carregarem constantemente em seu bojo um dilema específico - lembrar ou esquecer? Por isso, as ressignificações da memória cangaceira desvelam variadas disputas por suas formas de significação na temporalidade nordestina, quer dizer, disputas de identidades regionais, seja entre nordestinos e os "outros” ou entre "eles” próprios.

Particularmente, o processo de "tombamento da Gruta de Angico" é significativo porque salienta distintos imbróglios entre instituições, grupos e indivíduos, uma vez que o tema é bastante sensível. A partir do que foi visto, nota-se como o martírio pelos cangaceiros tem peso considerável nas negociações de conflitos, talvez porque o sentimento do sofrimento tende a unir mais do que o sentimento da alegria. As ações promovidas pelo Centro de Cultura Popular Zé Julião elucidam a situação, pois seus efeitos são criações de encargos de responsabilidade pelo passado que incentivam rememorações para que experiências semelhantes não vinguem. A lentidão do desfecho do processo em âmbito estadual, que tramitou por mais de uma década, e a sua falta de conclusão em esfera federal, guardado em alguma gaveta até os dias atuais, sugere questões que demandam análises para além dos documentos que foram arquivados e dos escopos desse artigo. Demais faces dessa cultura mnemônica precisam ser, evidentemente, pesquisadas.

De todo modo, percebe-se como desse cenário em relevo surgiu uma série de atribuições de valores a locais, bens e práticas que parecem convergir em direção à construção direta ou indireta de um patrimônio cultural nordestino reivindicado, dissonante e contestado. O patrimônio é reivindicado porque, ao emergir de vozes alternativas à memória instituída, suscita valorações que se distanciam da definição tradicional de herança cultural; dissonante 
porque há grande dissenso em torno do seu valor na temporalidade nordestina, seja em contestação ao seu valor enquanto elemento identitário nordestino ou por falta de acordo quanto a algumas valorações que, embora não rompam a ligação de identidade, são impugnados porque se chocam com identidades nordestinas cristalizadas; e contestado porque há questionamentos à vinculação identitária entre o fenômeno e a região.

\section{Notas:}

\footnotetext{
${ }^{1}$ A ideia remonta a plebiscito para a construção de Estátua para Lampião (1991), em Serra Talhada-PE. "Lampião: nem bandido, nem herói, ele é história! Vote sim" foi o slogan utilizado pelos favoráveis à estátua com nítida intenção de evitar polarização. Isso não foi suficiente para que alguns grupos contrários à intenção não fizessem ameaças de explosão em caso de efetiva construção do monumento. $C f$. CLEMENTE, Marcos Edilson de. Lampiões acesos. São Cristóvão: Editora UFS; Aracaju: Fundação Oviêdo Teixeira, 2009.

${ }^{2} \mathrm{O}$ local é conhecido popularmente como Grota, mas na documentação do seu tombamento é usada a expressão Gruta, a qual mantemos na escrita deste texto.

${ }^{3}$ Conselho Estadual de Cultura de Sergipe (CEC-SE). Processo do Tombamento da Gruta de Angico. Iniciado em 14 de maio de 1982, com tombamento em 1989 e finalizado em 26 de dezembro de 1996. Autoria do economista Luiz Fernando Ribeiro Soutelo, na época presidente do CEC-SE. In: Subsecretaria de Estado do Patrimônio Histórico e Cultural de Sergipe (SUBPAC-SE).

${ }^{4}$ A midiatização das narrativas históricas em minisséries na Globo foi iniciada com essa minissérie.

5 "Incidente em Angico". Gazeta de Sergipe, Aracaju, 12 de maio 1982. Editorial, p. 2.

${ }^{6}$ Conselho Estadual de Cultura de Sergipe (CEC-SE). Op. cit., p. 2.

${ }^{7}$ Ibidem, p. 5-7. A citação dentro da justificativa é do intelectual sergipano Manoel Bonfim, presente em sua obra Brasil Nação, publicada em 1931.

${ }^{8}$ Alcino Alves da Costa foi prefeito por três vezes, entre meados de 1960 e fim de 1980

${ }^{9}$ Conselho Estadual de Cultura de Sergipe (CEC-SE). Op. cit., p. 65-72.

${ }^{10}$ Ibidem, p. 89.

${ }^{11}$ Ibidem, p. 58-64. Um dos eventos realizados pelo Centro foi, em 1990, os 40 anos do fim do cangaço.

12 "O Serviço do Patrimônio Histórico e Artístico Nacional - SPHAN, criado pela Lei no 378, de 13 de janeiro de 1937, teve diferentes nomenclaturas em sua história, tais como DPHAN e IPHAN. Para fins didáticos, usaremos apenas a sigla IPHAN.

${ }^{13}$ Nessa época, a Secretaria de Cultura de Sergipe estava integrada à Secretaria de Meio Ambiente, mas, para facilitar a compreensão textual, continuaremos tratando no texto apenas como Secult-SE.

${ }^{14}$ Conselho Estadual de Cultura de Sergipe (CEC-SE). Op. cit., p. 26.

${ }^{15}$ Ibidem, p. 46.

${ }^{16}$ Ibidem, p. 24, 34 e 35.

${ }^{17}$ O Terreiro dos Filhos de Obá, Laranjeiras, foi tombado em 1988.

${ }^{18}$ Conselho Estadual de Cultura de Sergipe (CEC-SE). Op. cit., p. 73 e 74.

${ }^{19}$ Ibidem, p. 79.

${ }^{20}$ Ibidem. Foi reaberto em 9 de abril de 2007. No do memorando no Iphan: 093/2007 (interno). Div. Técnica. $8^{\mathrm{a}}$ $\mathrm{SR} / \mathrm{SE}$

${ }^{21}$ Disponível em: <http://www.sergipetec.org.br/biotecnologia_noticias/370/Inaugurado-Monumento-NaturalGrota-do-Angico.htm> Acesso em 20 jun. 2018.

${ }^{22}$ RENAN, Ernest apud CANDAU, Jöel. Memória e identidade. São Paulo: Contexto, 2012, p. 151.

${ }^{23}$ POMIAN, Krzysztof Apud HARTOG, François. Regimes de historicidade. Belo Horizonte: Autêntica Editora, 2013.p. 197.
}

\section{Referências Bibliográficas}

ALBUQUERQUE Jr, Durval Muniz de. Feira dos Mitos: a fabricação do folclore e da 
cultura popular (Nordeste 1920 - 1950). São Paulo: Intermeios, 2013.

ANDERSON, Benedict. Comunidades Imaginadas: Origem e difusão do nacionalismo. São Paulo: Companhia das Letras, 2008.

ARAÚJO SÁ, Antônio Fernando de. Combates entre história e memórias. São Cristovão: Editora da UFS; Aracaju: Fundação Oviêdo Teixeira, 2005.

. O cangaço nas batalhas da memória. Recife: Ed. Universitária UFPE, 2011.

ASHWORTH, G..J., GRAHAM, Brian, TUNBRIDGE, J.E. Pluralising Pasts: Heritage, Identity and Place in Multicultural Societies. London: Pluto Press, 2007.

ASSMANN, Aleida. Espaços da Recordação: formas e transformações da memória cultural. Campinas, SP: editora da Unicamp, 2011.

BARROS, Luitgarde Oliveira Cavalcanti. A derradeira gesta: Lampião e Nazarenos guerreando no sertão. $2^{\mathrm{a}}$ ed. Rio de Janeiro: Mauad, 2007.

CANDAU, Jöel. Memória e identidade. São Paulo: Contexto, 2012.

CLEMENTE, Marcos Edilson de. Lampiões acesos: o cangaço na memória coletiva. São Cristóvão: Editora UFS; Aracaju: Fundação Oviêdo Teixeira, 2009.

FALCÃO, Marcílio Lima. Jararaca: memória e esquecimento nas narrativas sobre um cangaceiro de Lampião em Mossoró. Mossoró: UERN, 2013

FERREIRA Jr, José. Serra Talhada x Triunfo: a disputa da memória de Lampião no médio Pajeú pernambucano. Tese de doutorado. Campina Grande: Universidade Federal de Campina Grande (UFCG), 2014.

GRUSPAN, Elise Jasmin. Lampião, senhor do sertão: vidas e mortes de um cangaceiro. São Paulo: Editora da Universidade de São Paulo, 2006.

HALL, Stuart. A identidade cultural na pós-modernidade. Rio de Janeiro: DP\&A. 2011.

HARTOG, François. Regimes de historicidade: presentismo e experiência do tempo. Belo Horizonte: Autêntica Editora, 2013.

HARVEY, David. Condição Pós-Moderna. Uma pesquisa sobre as origens da mudança cultural. São Paulo: Edições Loyola, 1992.

HEYMANN, Luciana \& ARRUTI, José Mauricio. "Memória e reconhecimento: notas sobre as disputas contemporâneas pela gestão da memória na França e Brasil". In: ROCHA, Helenice et. all (org.). Qual o valor da história hoje? Rio de Janeiro: Editora da Fundação Getúlio Vargas, 2012.

HOBSBAWM, Eric. Bandidos. 4ª ed. São Paulo: Paz e Terra, [1969] 2010.

HUYSSEN, Andreas. Culturas do passado-presente: modernismos, artes visuais, políticas da memória. $1^{\text {a }}$ ed. Rio de Janeiro: Contraponto: Museu de Arte do Rio, 2014.

KOSELLECK, Reinhart. Estratos do tempo: estudos sobre história. Rio de Janeiro: Editora PUC-Rio, 2014.

MELLO, Frederico Pernambucano. Guerreiros do sol: violência e banditismo no Nordeste do Brasil. São Paulo: A Girafa Editora, 2004.

MENEGUELO, Cristina. "Patrimônios sombrios, memórias difíceis". In: FLORES, Maria Bernardete Ramos \& PETERLE, Patricia (org.) História e arte: herança, memória e patrimônio. São Paulo: Rafael Copetti Editor, 2014, p.46-66.

NOGUEIRA, Antonio Gilberto Ramos. "O campo do patrimônio cultural e a história: itinerários conceituais e práticas de preservação."Antíteses, v.7, n.14, Londrina, 2014, p. 4567.

NORA, Pierre. "Entre memória e história: a problemática dos lugares". Projeto História. São Paulo, n.10, dez. 1993.

PASSOS, Lucas Santos; NASCIMENTO, Maíra Ielena. "Elite intelectual e patrimônio cultural no Conselho Estadual de Cultura de Sergipe". In: IV Seminário Internacional Políticas Culturais. (Anais). RJ, Fundação Casa de Rui Barbosa, Setor de Políticas Culturais, 
2013.

PEREIRA, Laurindo Mékie. "Cidadania ampliada - lutas contemporâneas". In: CARDOSO, Heloisa Helena Pacheco \& PATRIOTA, Rosangela. (org.) Escritas e Narrativas Históricas na Contemporaneidade. Belo Horizonte: Fino Traço, 2011.

PERICÁS, Luiz Bernardo. Os Cangaceiros: ensaio de interpretação histórica. São Paulo: Boitempo, 2010.

POLLAK, Michael. "Memória, Esquecimento e Silêncio". In: Estudos Históricos, Rio de Janeiro, vol. 2, n. 3, 1989, p. 3-15.

POULOT, Dominique. Uma história do patrimônio no Ocidente. São Paulo: Estação liberdade, 2009.

QUEIROZ, Maria Isaura Pereira de. Os Cangaceiros. São Paulo: Duas Cidades, 1977.

RAMOS FILHO, Vagner Silva. "Século Virgulino": o cangaço nas (con)fusões da memória entre comemorações de Lampião no tempo presente. Dissertação de Mestrado em História. Universidade Federal do Ceará (UFC), 2016.

"(O)culto pelo patrimônio: (pre)tensões da memória do cangaço na cultura nordestina". In: CUNHA FILHO, F. H.; BOTELHO, I; SEVERINO, J. R (orgs.). Direitos Culturais. Salvador: EDUFBA, 2018, p. 189-208. (Cultura e pensamento; 1).

REIS, José Carlos. Teoria \& História. Tempo histórico, história do pensamento histórico ocidental e pensamento brasileiro. Rio de Janeiro: Editora FGV, 2012.

RICOEUR, Paul. Memória, História e Esquecimento. Campinas: Ed. da Unicamp, 2007.

SARLO, Beatriz. Paisagens Imaginárias: Intelectuais, Arte e Meios de Comunicação. São Paulo: Editora da Universidade de São Paulo, 2005.

VARELLA, Flávia Florentino (org.). [et al]. Tempo presente \& usos do passado. Rio de Janeiro: Editora FGV, 2012.

WIESEBRON, Marianne L. "Historiografia do cangaço e estado atual da pesquisa sobre o banditismo a nível nacional e internacional". In: Coleção Mossoroense (Fundação Vingt-un Rosado), Série “A”, nº 90, Mossoró, 1997.

WINTER, Jay. "A geração da memória: reflexões sobre o 'boom da memória' nos estudos contemporâneos de história”. In: SELIGMANN-SILVA, Márcio (org.). Palavra e imagem: memória e escritura. Chapecó: Argos, 2006, p. 67-90. 